\title{
Neither bovine somatotropin nor growth hormone-releasing factor alters expression of thyroid hormone receptors in liver and mammary tissues ${ }^{1}$
}

\author{
A. V. Capuco,${ }^{* 2}$ M. Binelli, $\dagger$ and H. A. Tucker $\ddagger^{3}$ \\ *Bovine Functional Genomics Laboratory, USDA-ARS, Beltsville, MD 20705 \\ †Department of Animal Reproduction, University of Sao Paulo, Pirassununga, SP 13635-900, Brazil \\ ‡Department of Animal Science, Michigan State University, East Lansing 48824
}

\section{ABSTRACT}

Physiological effects of thyroid hormones are mediated primarily by binding of triiodothyronine to specific nuclear receptors. Organ-specific changes in production of triiodothyronine from its prohormone, thyroxine, have been hypothesized to target the action of thyroid hormones on the mammary gland and play a role in mediating or augmenting a galactopoietic response to bovine somatotropin (bST). Additionally, tissue responsiveness to thyroid hormones may be altered by changes in the number or affinity of nuclear receptors for thyroid hormones. In the present study, effects of bST and bovine growth hormone-releasing factor (bGRF) on thyroid hormone receptors in liver and mammary gland were studied. Lactating Holstein cows received continuous infusions of bST or bGRF for $63 \mathrm{~d}$ or served as uninfused controls. Nuclei were isolated from harvested mammary and liver tissues and incubated with $\left[{ }^{125} \mathrm{I}\right]$-triiodothyronine. Treatments did not alter the capacity or affinity of specific binding sites for triiodothyronine in liver or mammary nuclei. Evaluation of transcript abundance for thyroid hormone receptors showed that isoforms of thyroid hormone receptor or retinoid receptor (which may influence thyroid receptor action) expressed in the mammary gland were not altered by bST or bGRF treatment. Data do not support the hypothesis that administration of bST or bGRF alters sensitivity of mammary tissue by changing expression of thyroid hormone receptors.

Key words: triiodothyronine, deiodinase, lactation, galactopoiesis

Received December 15, 2010.

Accepted June 22, 2011.

${ }^{1}$ Mention of trade names or commercial products in this article is solely for the purpose of providing specific information and does not imply recommendation or endorsement by the US Department of Agriculture. The USDA is an equal opportunity provider and employer.

${ }^{2}$ Corresponding author: tony.capuco@ars.usda.gov

${ }^{3}$ Deceased July 15, 2009.

\section{INTRODUCTION}

Thyroid hormones are important for maintenance of normal lactation (Tucker, 1981). Nevertheless, lactating animals are often in a functional hypothyroid state as compared with nonlactating animals (Fukuda et al., 1980; Blum et al., 1983; Refsal et al., 1984; Aceves and Valverde, 1989). During lactation, thyroid hormone metabolism is altered in an organ-specific manner consistent with maintaining the mammary gland in a euthyroid condition despite the prevalent hypothyroid status of the animal (Kahl et al., 1987; Valverde-R and Aceves, 1989; Jack et al., 1994; Pezzi et al., 2003). Additionally, during the transition from pregnancy to lactation, alterations in expression of thyroid hormone receptors (TR) and retinoid X receptors (RXR) seemingly supplement organ-specific changes in thyroid hormone metabolism to increase sensitivity of mammary tissue to thyroid hormones (Capuco et al., 2008).

Thyroid hormones are galactopoietic (Graham, 1934) and play a role in modulating the response to other galactopoietic hormones. In response to administration of bST or bovine growth hormone-releasing factor (bGRF), the action of thyroid hormones may be preferentially targeted to the mammary gland due to increased generation of the active thyroid hormone, triiodothyronine $\left(\mathbf{T}_{3}\right)$, within the mammary glands and decreased generation in other organs (Capuco et al., 1989; Kahl et al., 1995). Preferentially targeting $\mathrm{T}_{3}$ generation to the mammary gland would promote the galactopoietic functions of $\mathrm{T}_{3}$ and focus metabolic priority on the mammary gland. Thus, it has been hypothesized that thyroid hormones may enhance or mediate the galactopoietic effects of bST and bGRF (Capuco et al., 1989). Indeed, data indicate that thyroid hormones are necessary to obtain a milk production increase in response to administration of growth hormone to mice (Capuco et al., 1999). A comparison of effects of bST and bGRF on body growth and lactation (Binelli et al., 1995), lipid and glucose metabolism (Liesman et al., 1995), thyroid hormone metabolism (Kahl et al., 1995), 
the somatotropic axis (Vanderkooi et al., 1995), and ovarian function (Jimenez-Krassel et al., 1999) have been reported.

Physiological effects of thyroid hormones are mediated by binding of $\mathrm{T}_{3}$ to specific nuclear receptors. However, the possibility that bST alters sensitivity of the mammary gland and peripheral tissues to thyroid hormones by virtue of effects on expression of nuclear TR has not been investigated. The objective of the present study was to determine if bST and bGRF treatment of lactating cows alters the number or affinity of TR in the mammary gland and liver.

\section{MATERIALS AND METHODS}

\section{Cows and Experimental Design}

Thirty primiparous Holstein cows were used in a split block design. The diet, facilities, and cow management were described previously (Binelli et al., 1995). In brief, cows were housed in tie-stalls and exposed to $24 \mathrm{~h}$ of light/d. They were milked 3 times daily and feed was offered twice daily for ad libitum intake. The feed, as a TMR, was formulated to provide adequate nutrition for a cow (590 kg of BW) producing $38.5 \mathrm{~kg} / \mathrm{d}$ of milk containing $3.5 \%$ fat and assuming an intake of 22.7 $\mathrm{kg}$ of DM/d (NRC, 1989). Ten blocks of 3 cows were formed based on calving date. Beginning on d 118 of lactation (experimental d 0), cows within a block were assigned randomly to receive continuous i.v. infusion of recombinant bGRF (1-45) homoserine lactone (Pharmacia \& Upjohn Inc., Kalamazoo, MI; 12 mg/d), bST (Somavubove; Pharmacia \& Upjohn Inc., $29 \mathrm{mg} / \mathrm{d}$ ), or nothing (controls). The recombinant bGRF and bST were infused in pulses at 3.75-min intervals for $63 \mathrm{~d}$ of treatment. Doses were selected based on a previous experiment (Dahl et al., 1993), in which the same doses elicited a similar concentration of somatotropin in serum. Liver and mammary tissue samples were obtained from each cow at slaughter on d 63 of treatment. Samples were collected from the same region of the liver and from the right rear quarter of the udder, midway between the gland cistern and supramammary fat pad. Tissues samples were rapidly frozen in liquid $\mathrm{N}_{2}$ and stored at $-80^{\circ} \mathrm{C}$ until assayed. Triiodothyronine binding studies were completed within 18 mo of tissue collection. Ribonucleic acid isolation and real-time quantitative reverse transcription (RT)-PCR was performed $11 \mathrm{yr}$ after tissue collection; however, the RNA recovered was of good quality (see below).

Use of animals for these investigations was approved by Michigan State University's Animal Care and Use Committee.

\section{Nuclear Preparation}

Mammary or liver tissues were homogenized (1:4, wt/ vol) in TSM buffer ( $25 \mathrm{~m} M$ Tris-HCl, $0.25 M$ sucrose, $1 \mathrm{mM} \mathrm{MgCl}$, and $1 \mathrm{~m} M$ dithiothreitol, $\mathrm{pH}$ 7.4) using a Tekmar homogenizer $(3 \times 10 \mathrm{~s}$ at 17,000 rpm; Tekmar, Cincinnati, OH). The homogenate was filtered through cheesecloth, adjusted to 10 volumes with TSM buffer, and centrifuged at 3,000 $\times g$ for $10 \mathrm{~min}$. The pellet was washed twice by vortexing in 10 volumes of TSM buffer containing 1\% Triton X-100 (Sigma Chemical Co., St. Louis, MO). After the second wash, resuspended nuclei were filtered through nylon mesh $(100 \mu \mathrm{m})$. The nuclei were then centrifuged $(1,000 \times g$ for $12 \mathrm{~min})$ and washed twice in 5 volumes of TSM buffer. The final pellet was resuspended in 2 volumes of TSM buffer.

\section{$T_{3}$ Binding}

Duplicate $200-\mu \mathrm{L}$ aliquots of nuclear suspension containing approximately $100 \mu \mathrm{g}$ of DNA were incubated in TSM buffer containing a fixed concentration (0.06 $\mathrm{n} M)$ of $\left[{ }^{125} \mathrm{~T}\right] \mathrm{T}_{3}\left(8.14 \times 10^{13} \mathrm{~Bq} / \mathrm{mmol} ;\right.$ New England Nuclear Corp., Boston, MA) and 7 concentrations (0.04 to $20 \mathrm{nM}$ ) of unlabeled $\mathrm{T}_{3}$ in a final volume of 500 $\mu \mathrm{L}$. In addition, the incubation mixture contained 100 kallikrein inhibitor units of aprotinin per milliliter and $1 \mathrm{~m} M$ phenylmethylsulfonyl fluoride (Sigma Chemical Co.). Addition of nuclei to the incubation buffer was the final step before incubation. Nonspecific binding was estimated as binding that occurred in the presence of 1,000 nM non-labeled $\mathrm{T}_{3}$. Tubes were incubated at $26^{\circ} \mathrm{C}$ for $110 \mathrm{~min}$. After incubation, tubes were cooled on ice and immediately centrifuged at $1,200 \times g$ for $10 \mathrm{~min}$. Aliquots of the supernatant were used to determine the quantity of receptors released from nuclei during incubation. Soluble receptors in the supernate were separated from free $\left[{ }^{125} \mathrm{~T}\right] \mathrm{T}_{3}$ using Dowex $1 \times 8$, chloride, 400 mesh, anion-exchange resin (BioRad, Hercules, CA), as described by Bernal and DeGroot (1977). The nuclear pellet was washed twice with $1 \mathrm{~mL}$ of icecold TSM buffer containing 1\% Triton X-100. Bound radioactivity in the supernatant and nuclear pellets was quantified (Cobra 5005 auto-gamma; Packard Instrument Co., Meriden, CT). Triiodothyronine that was specifically bound (binding in nuclei plus supernatant) was analyzed according to Scatchard (1949) using the EBDA/LIGAND program (KELL; Biosoft, Milltown, NJ), to calculate binding affinities and binding capacities.

Binding affinities of nuclear binding sites for $\mathrm{T}_{3}, \mathrm{~T}_{4}$, and $3,3^{\prime}, 5^{\prime}$-triiodothyronine $\left(\mathbf{r} \mathbf{T}_{\mathbf{3}}\right)$ were tested. Nuclei from the mammary gland and liver were incubated at 
$26^{\circ} \mathrm{C}$ for 110 min with $0.06 \mathrm{n} M\left[{ }^{125} \mathrm{I}^{\mathrm{T}} \mathrm{T}_{3}\right.$ and concentrations of competitor ranging from 0.2 to $10,000 \mathrm{n} M$. Binding was quantified as above (nuclear bound plus soluble receptors) and relative binding affinities were determined (KELL; Biosoft).

Binding stability and hormone exchange rates at 0 , 24 , and $37^{\circ} \mathrm{C}$ were characterized to determine the extent to which the binding assay measures free or total receptors. Nuclei were pre-incubated for 90 min at $24^{\circ} \mathrm{C}$ with $0.06 \mathrm{n} M$ of $\left[{ }^{125} \mathrm{~T}\right] \mathrm{T}_{3}$ to achieve maximal binding. Once again, nonspecific binding was estimated as binding that occurred in the presence of 1,000 $\mathrm{n} M$ non-labeled $\mathrm{T}_{3}$. At equilibrium (after 90 a min preincubation, 0 min of exchange), non-labeled $\mathrm{T}_{3}$ was added to a final concentration of 1,000 $\mathrm{nM}$ and tubes incubated at 0 , 24 , and $37^{\circ} \mathrm{C}$ for 30 to $120 \mathrm{~min}$ to assess dissociation of ligand from nuclear binding sites. Additionally, nuclei were maintained without the addition of non-labeled $\mathrm{T}_{3}$ after the initial 90-min incubation to evaluate stability of binding at the various temperatures (i.e., in the absence of ligand exchange).

\section{DNA Determination}

Quantity of DNA in nuclear preparations was determined by the method of Labarca and Paigen (1980), using calf thymus DNA (Sigma Chemical Co.) as the standard.

\section{RNA Preparation and Real-Time Quantitative RT-PCR}

Total RNA was isolated from mammary tissue of 5 randomly selected cows per treatment using RNeasy isolation kits with on-column DNase digestion (Qiagen Inc., Valencia, CA). The RNA quality was evaluated using the Agilent 2100 Bioanalyzer with RNA 6000 Nano LabChip kits (Agilent Technologies Inc., Palo Alto, CA) and concentration was determined using a NanoDrop ND-1000 spectrophotometer (NanoDrop Technologies Inc., Rockland, DE). The mean RNA integrity number was 7.4 (range 7.2 to 8.0). Reverse transcription was performed using the iScript cDNA synthesis kit (Bio-Rad) with $1 \mu \mathrm{g}$ of RNA per $40-\mu \mathrm{L}$ reaction volume. Incubation conditions were those suggested by the manufacturer: $25^{\circ} \mathrm{C}$ for $5 \mathrm{~min}, 42^{\circ} \mathrm{C}$ for 30 min, and $85^{\circ} \mathrm{C}$ for $5 \mathrm{~min}$. Parallel reactions were performed in the absence of reverse transcriptase enzyme to serve as negative control for real-time PCR.

Transcript abundance was determined by absolute real-time quantitative RT-PCR using the Bio-Rad iCycler with a MyiQ Real-time PCR Detection System, and using iQ SYBR Green Supermix (Bio-Rad Laboratories Inc.). Primer sequences, conditions for real-time quantitative PCR, and validation were described previ- ously (Capuco et al., 2008). Quantities of transcripts were expressed as the number of molecules per unit of total RNA used in the reverse transcription reaction.

\section{Statistical Analysis}

Data were analyzed using a one-way ANOVA. The Bonferroni multiple comparison test was used for pairwise comparisons (Prism, version 4; GraphPad Software Inc., San Diego, CA).

\section{RESULTS AND DISCUSSION}

Specific binding of $\mathrm{T}_{3}$ to nuclei from bovine liver or mammary gland was maximal within 60 min of incubation at room temperature (Figure 1). Data presented in this figure represents the total quantity of ligand that remained bound to TR in nuclei plus that which was bound and released into the supernatant during incubation. During incubation of mammary nuclei, specific binding remained associated with the nucleus, whereas during incubation of liver nuclei, approximately $20 \%$ of specifically bound $\mathrm{T}_{3}$ was released into the supernatant by the end of the incubation period (data not shown). The release of $\left[{ }^{125} \mathrm{I}\right] \mathrm{T}_{3}$-labeled nuclear receptors during incubation was analogous to that originally described for rat liver nuclei (Bernal and DeGroot, 1977). A possible biological significance of the retention of nuclear TR by mammary nuclei remains to be determined.

Incubation of nuclei with $\left[{ }^{125} \mathrm{I}\right] \mathrm{T}_{3}$ and varying concentrations of non-labeled thyroid hormones indicated that binding affinities were in the order $\mathrm{T}_{3}>\mathrm{T}_{4}>\mathrm{rT}_{3}$ (Figure 2). In liver and mammary nuclei, the binding affinities for $\mathrm{T}_{4}$ and $\mathrm{rT}_{3}$ relative to the affinity for $\mathrm{T}_{3}$ were 4 to $9 \%$ and $0.3 \%$, respectively. This is in agreement with the specificity of TR from various tissues of other species (Oppenheimer, 1979) and with the biological potencies of these hormones (Oppenheimer and Schwartz, 1986; Silva and Larsen, 1986; Oppenheimer et al., 1987). In contrast, the only other report of $\mathrm{T}_{3}$ binding in bovine mammary tissue measured cytosolic rather than nuclear binding and reported hormone specificity that is inconsistent with the biology of a TR (Wilson and Gorewit, 1980).

Preliminary data (not shown) indicated that maximal binding was obtained when nuclei were incubated with $\left[{ }^{125} \mathrm{I}\right] \mathrm{T}_{3}$ at room temperature. To further investigate the kinetics of specific binding of $\left[{ }^{125} \mathrm{I}\right] \mathrm{T}_{3}$ in mammary nuclei, nuclei were pre-incubated with $\left[{ }^{125} \mathrm{I}\right] \mathrm{T}_{3}$ to achieve maximal binding and then an excess of non-labeled $\mathrm{T}_{3}$ was added and incubations continued at 0,24 , and $37^{\circ} \mathrm{C}$ to evaluate displacement of $\left[{ }^{125} \mathrm{I}\right] \mathrm{T}_{3}$. At $37^{\circ} \mathrm{C}$, the majority of bound ligand dissociated within $2 \mathrm{~h}$ (Figure $3 \mathrm{~A})$. Less displacement $(\sim 40 \%)$ occurred at $24^{\circ} \mathrm{C}$ 


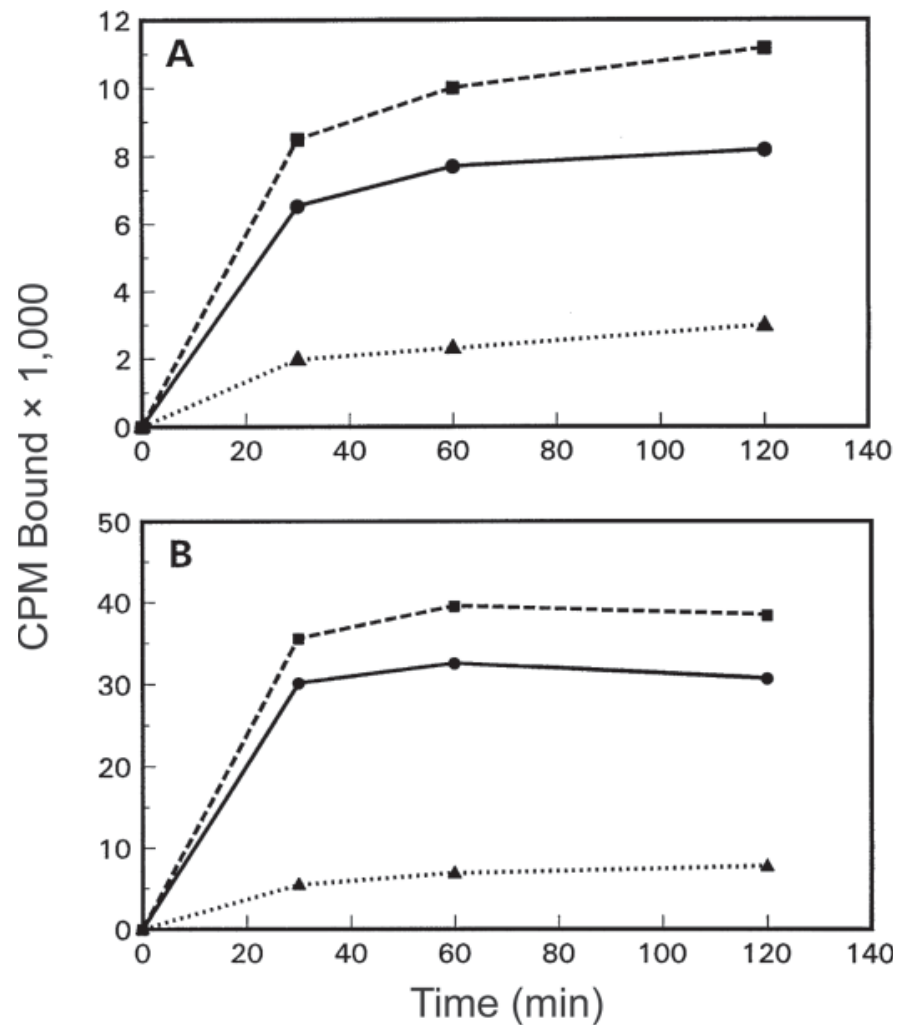

Figure 1. Time course of nuclear triiodothyronine $\left(\mathrm{T}_{3}\right)$ binding. Nuclei from the mammary gland (panel A) and liver (panel B) were incubated at $26^{\circ} \mathrm{C}$ with $0.06 \mathrm{nM}\left[{ }^{125} \mathrm{I}\right] \mathrm{T}_{3}$ in the presence and absence of $1,000 \mathrm{n} M$ non-labeled $\mathrm{T}_{3}$. Binding in the presence of excess nonlabeled $\mathrm{T}_{3}$ was considered to be nonspecific binding. Specific binding was calculated as the difference between total and nonspecific binding. $\mathrm{CPM}=$ counts per minute. $\mathbf{\square}=$ total binding, $\boldsymbol{\bullet}=$ specific binding, $\boldsymbol{\Delta}=$ nonspecific binding.

and the least displacement occurred at $0^{\circ} \mathrm{C}$. Although these data suggested that incubation at $37^{\circ} \mathrm{C}$ might be appropriate to facilitate exchange with endogenously bound ligand and thus permit determination of total TR number, specific binding of $\left[{ }^{125} \mathrm{I}\right] \mathrm{T}_{3}$ was not stable at $37^{\circ} \mathrm{C}$ (Figure $3 \mathrm{~B}$ ). Even in the absence of non-labeled ligand, specific binding decreased when pre-labeled nuclei were subsequently incubated at $37^{\circ} \mathrm{C}$. This result is consistent with denaturation or degradation of TR, despite addition of proteolytic inhibitors. Specific binding was relatively stable at 0 and $24^{\circ} \mathrm{C}$. Accordingly, we selected incubation at room temperature $\left(24\right.$ to $\left.26^{\circ} \mathrm{C}\right)$ for these binding studies. At room temperature, binding was rapid and stable, and the assay measured primarily unoccupied binding sites for $\mathrm{T}_{3}$.

Treatment of lactating Holstein cows with bST or bGRF did not alter the number or affinity of specific binding sites for $\mathrm{T}_{3}$ in the liver and mammary gland (Table $1 ; P>0.05)$. The dissociation constant $\left(\mathrm{K}_{\mathrm{d}}\right)$ for specific nuclear binding of $\mathrm{T}_{3}$ averaged 0.13 and 0.38

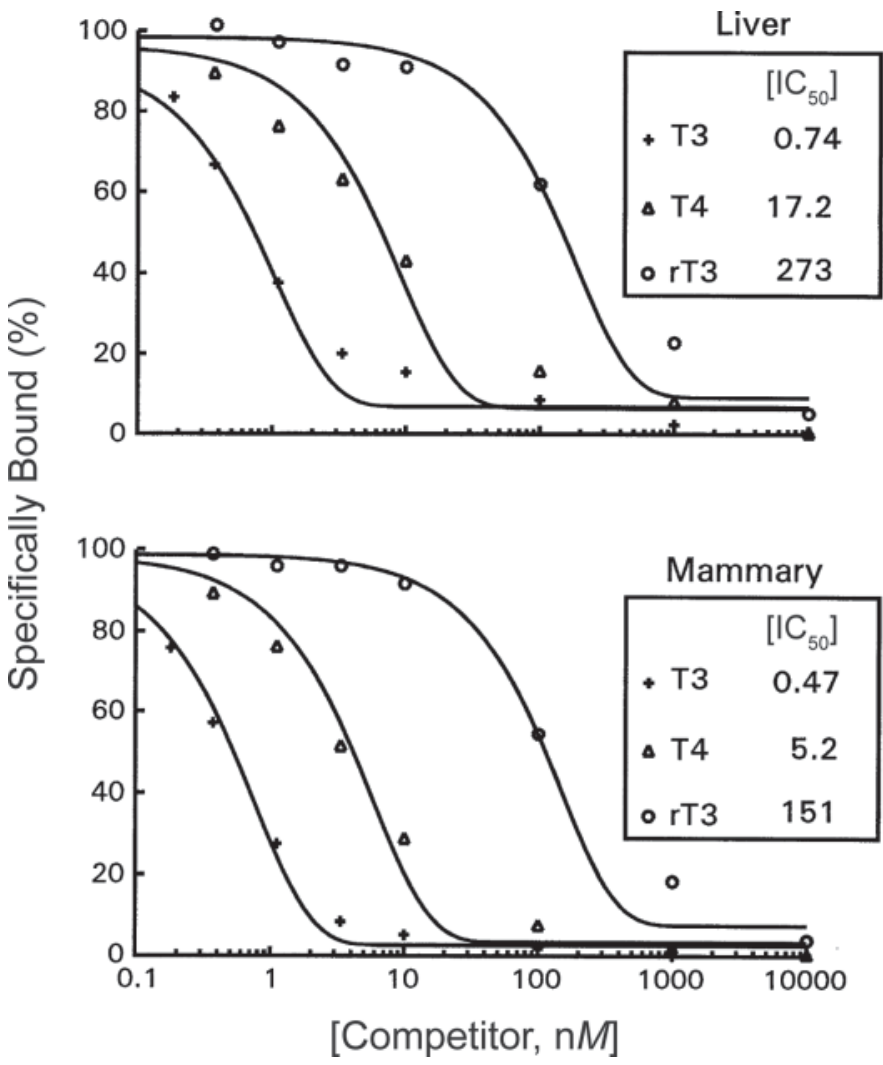

Figure 2. Specificity of nuclear triiodothyronine $\left(\mathrm{T}_{3}\right)$ binding. Nuclei from the mammary gland and liver were incubated at $26^{\circ} \mathrm{C}$ with $0.06 \mathrm{n} M\left[{ }^{125} \mathrm{I}\right] \mathrm{T}_{3}$ and varying concentrations of non-labeled $\mathrm{T}_{3}, \mathrm{~T}_{4}$, and $3,3^{\prime}, 5^{\prime}$-triiodothyronine $\left(\mathrm{rT}_{3}\right)$. Specific binding at various concentrations of inhibitor is expressed as a percentage of the $\left[{ }^{125} \mathrm{I}\right] \mathrm{T}_{3}$ specifically bound in the absence of competitor. The concentration of competitor inhibiting $50 \%$ of specific binding $\left(\mathrm{IC}_{50}\right)$ is indicated.

$n M$ for mammary and liver tissues, respectively, and binding capacities averaged 12.5 and $21.2 \mathrm{fmol} / 100 \mu \mathrm{g}$ of DNA. As with other parameters investigated using these cows, no evidence existed for galactopoietic effects of bGRF beyond those resulting from somatotropin release (Binelli et al., 1995; Kahl et al., 1995; Liesman et al., 1995; Vanderkooi et al., 1995). Furthermore, these data do not support the hypothesis that somatotropin alters tissue sensitivity to thyroid hormones by changing the number or affinity of nuclear TR. However, a change in the isoforms of TR may not be detectable by ligand binding.

Although Scatchard analysis of binding data in the present (Figure 4) and previous studies (Oppenheimer, 1979; Oppenheimer and Schwartz, 1986; Silva and Larsen, 1986; Oppenheimer et al., 1987) suggest the presence of a single class of nuclear receptor, molecular approaches have indicated the presence of several forms of thyroid hormone receptor. Thyroid hormone receptors are members of the superfamily of steroid hormone 
Table 1. Binding of triiodothyronine to hepatic and mammary nuclei ${ }^{1}$

\begin{tabular}{|c|c|c|c|c|}
\hline \multirow[b]{2}{*}{ Item } & \multicolumn{2}{|c|}{ Liver nuclei } & \multicolumn{2}{|c|}{ Mammary nuclei } \\
\hline & $\mathrm{K}_{\mathrm{d}}^{2}$ & $\mathrm{~B}_{\max }^{3}$ & $\mathrm{~K}_{\mathrm{d}}$ & $\mathrm{B}_{\max }$ \\
\hline Control & 0.38 & 17.3 & 0.13 & 11.9 \\
\hline bST & 0.40 & 25.1 & 0.13 & 12.2 \\
\hline $\mathrm{bGRF}^{4}$ & 0.37 & 20.1 & 0.13 & 13.4 \\
\hline SEM & 0.09 & 3.0 & 0.03 & 2.0 \\
\hline$P$-value & 0.93 & 0.22 & 0.99 & 0.84 \\
\hline
\end{tabular}

${ }^{1}$ Values are means for 10 cows/treatment.

${ }^{2} \mathrm{~K}_{\mathrm{d}}=$ dissociation constant $(\mathrm{n} M)$.

${ }^{3} \mathrm{~B}_{\max }=$ binding capacity (fmol/100 $\mu \mathrm{g}$ of DNA).

${ }^{4}$ Bovine growth hormone-releasing factor.

receptors that are $\operatorname{erb} A$ proto-oncogenes (Weinberger et al., 1986; Sap et al., 1986; Falcone et al., 1992). In the absence of ligand, these receptors bind to thyroid re-

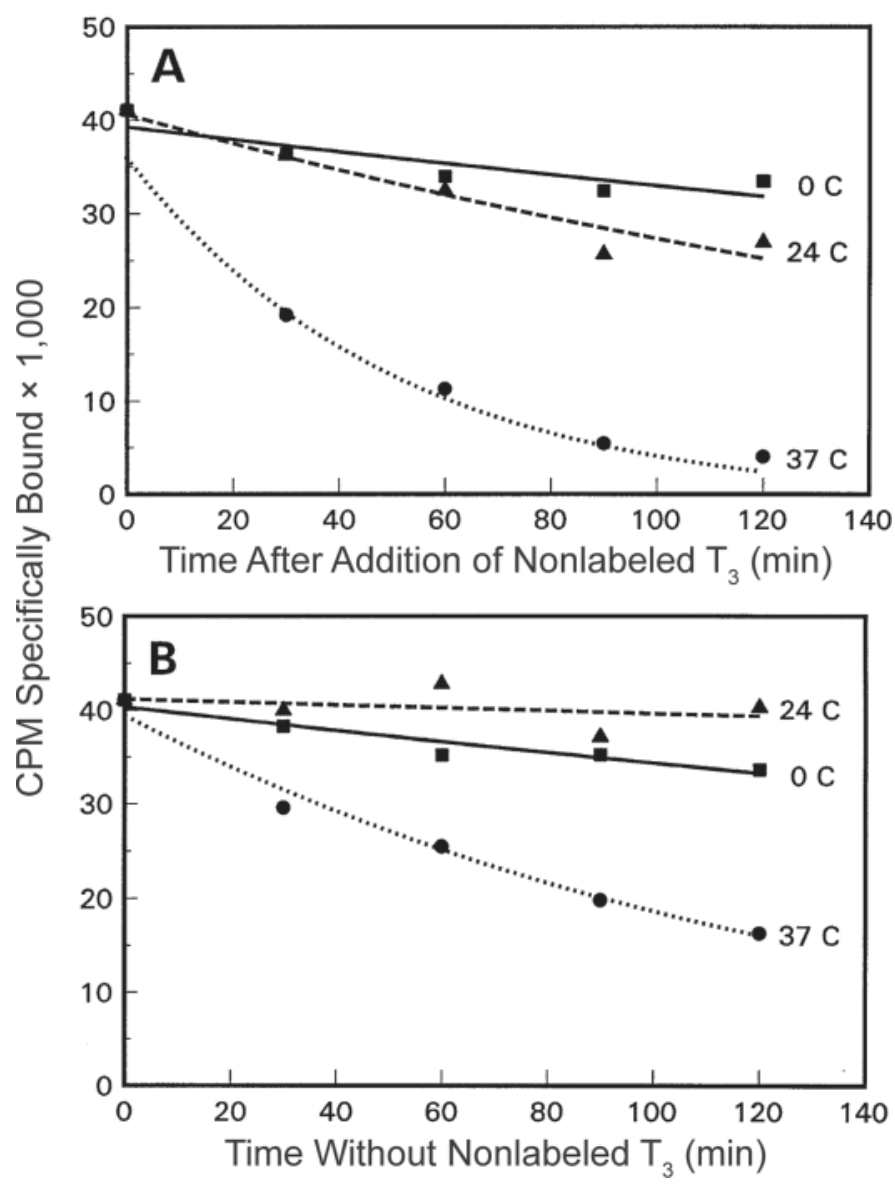

Figure 3. Characterization of binding stability and hormone exchange rate at 0,24 , and $37^{\circ} \mathrm{C}$. Mammary nuclei were pre-incubated for $90 \mathrm{~min}$ at $24^{\circ} \mathrm{C}$ with ${ }^{125} \mathrm{I}$-triiodothyronine $\left(\left[{ }^{125} \mathrm{I}\right] \mathrm{T}_{3}\right)$ in the presence and absence of 1,000 $\mathrm{n} M$ non-labeled $\mathrm{T}_{3}$. Panel A: At equilibrium (90 min pre-incubation, 0 time of exchange), 1,000 $\mathrm{n} M$ non-labeled $\mathrm{T}_{3}$ was added to assess the dissociation of ligand from nuclear receptors at different temperatures. Panel B: 1,000 $\mathrm{n} M$ non-labeled $\mathrm{T}_{3}$ was not added to follow the stability of binding in the absence of ligand exchange. $\mathrm{CPM}=$ counts per minute. sponse elements and repress expression of target genes by virtue of interaction with co-repressors (Oetting and Yen, 2007). Two classes of TR are produced by 2 genes, THRA and THRB, seemingly present in all mammalian tissues (DeGroot et al., 1989; Falcone et al., 1992), which encode the receptors $\operatorname{TR} \alpha$ and $\operatorname{TR} \beta$, respectively. Additionally, splice variants of $\mathrm{TR} \alpha$ and $\mathrm{TR} \beta$ exist. Interestingly, the TR $\alpha 2$ variant has been implicated as an inhibitor of thyroid hormone action because it does not bind thyroid hormones but binds to thyroid response elements and, thus, serves as a repressor. The TR dimerize and bind to thyroid response elements as homodimers or heterodimers with RXR. Because the ligand-bound TR predominantly bind to thyroid response elements as heterodimers with RXR rather than

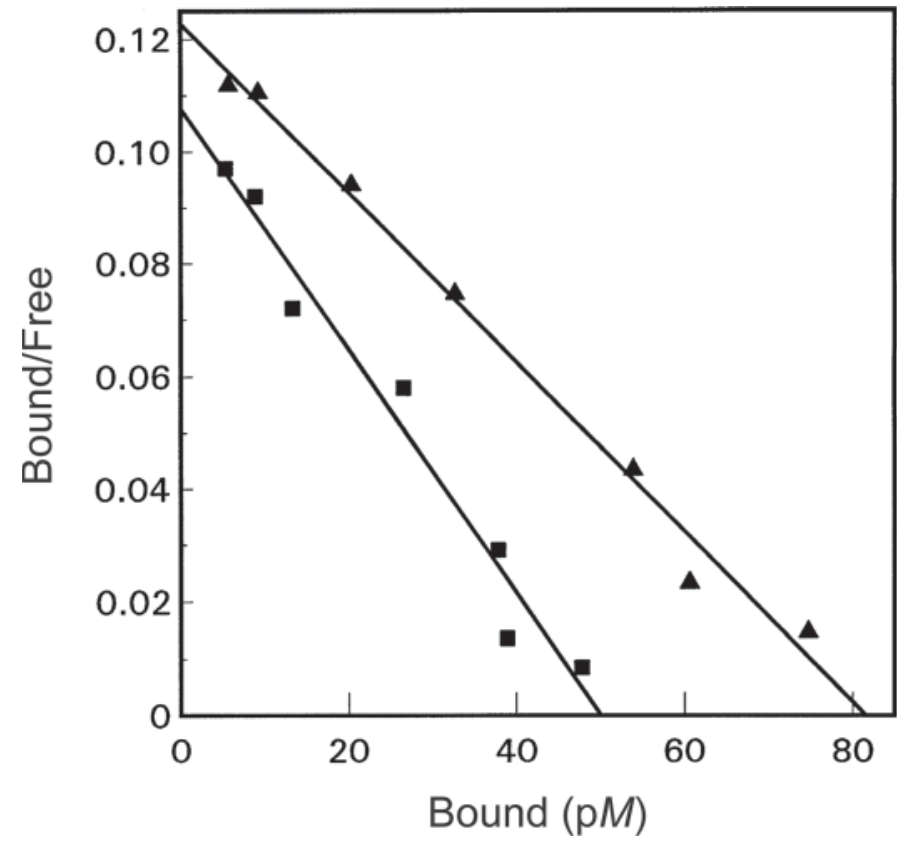

Figure 4. Scatchard plot of triiodothyronine $\left(\mathrm{T}_{3}\right)$ binding to nuclei isolated from bovine liver $(\boldsymbol{\Lambda})$ and mammary tissue $(\boldsymbol{\square})$. Singlecomponent binding was evident in both tissues with dissociation constants of 0.4 and $0.7 \mathrm{n} M$ for mammary and liver nuclei, respectively. 
Table 2. Abundance of transcripts for thyroid hormone receptor (TR) and retinoid receptor (RX) isoforms in mammary tissue ${ }^{1}$

\begin{tabular}{lccccc}
\hline & \multicolumn{5}{c}{ Molecules per unit RNA used in reverse-transcription reaction } \\
\cline { 2 - 6 } Item & TR $\alpha 1$ & TR $\alpha 2$ & TR $\beta 1$ & RXR $\alpha$ & RXR $\gamma$ \\
\hline Control & 3,956 & 5,406 & 4,852 & 381 & 58 \\
bST & 5,298 & 5,098 & 5,586 & 385 & 48 \\
bGRF & 5,124 & 4,676 & 5,344 & 429 & 45 \\
SEM & 1,258 & 550 & 318 & 56 & 14 \\
$P$-value & 0.72 & 0.65 & 0.29 & 0.59 & 0.80 \\
\hline
\end{tabular}

${ }^{1}$ Values are means for 5 cows/treatment.

${ }^{2}$ Bovine growth hormone-releasing factor.

as TR homodimers (Yen, 2001), RXR expression likely has a significant effect on mediating biological responses to thyroid hormones. We recently demonstrated that the transition from pregnancy to lactation is accompanied by increased expression of TR $\beta 1$ and decreased expression of RXR $\alpha$, which may increase sensitivity of mammary tissue to thyroid hormones (Capuco et al., 2008). Accordingly, we characterized the abundance of transcripts for the TR isoforms, TR $\alpha 1$, TR $\alpha 2$, and TR $\beta 1$, and for retinoid receptor isoforms, RXR $\alpha$ and $\operatorname{RXR} \gamma$, in the present study.

Administration of bST or bGRF did not alter the mRNA expression profile for TR or RXR isoforms in mammary tissue (Table 2), although treatment clearly increased milk yield (Binelli et al., 1995). Previous research has suggested that somatotropin targets thyroid hormone action to the mammary gland by decreasing activation of thyroid hormones in peripheral tissues, such as liver, or by enhancing their activation and decreasing their inactivation in mammary tissue (Capuco et al., 1989; Kahl et al., 1995; Capuco et al., 1999; Capuco et al., 2008). Data from the current analyses suggest that effects of bST on thyroid hormone metabolism are not augmented by increased sensitivity of mammary tissue to thyroid hormones, via altered expression of TR. Although tissue used for TR transcript profiling was archived at $-80^{\circ} \mathrm{C}$ for many years before RT-PCR, the isolated RNA was of good quality and the transcript profile was analogous to that obtained in a more recent study (Capuco et al., 2008), supporting the validity of the obtained results.

Although administration of bST or bGRF did not alter the quantity or affinity of TR in mammary or liver tissues, the $\mathrm{T}_{3}$-binding capacity was greater in liver than in mammary tissue and $\mathrm{T}_{3}$-binding affinity greater in mammary tissue than liver (Table $1 ; P$ $<0.0001)$. A difference in affinity between liver and mammary tissues may be due to differences in activity of co-regulators in the 2 tissues or differences in TR isoforms that are expressed in the tissues. Because liver tissue was not available for analysis of TR isoforms, we were unable to evaluate their abundance in liver. However, the abundance of TR $\beta 1$ transcripts in human and rodent liver is more than 10 -fold greater than the abundance of other TR isoforms in this tissue (Harvey and Williams, 2002; Keijzer et al., 2007), in contrast to almost equal abundance of the TR isoforms in the bovine mammary gland. This suggests that expression of TR isoforms may differ between mammary and liver tissues and may have contributed to the differing $\mathrm{K}_{\mathrm{d}}$ values for $T_{3}$ binding in these tissues.

In summary, $\mathrm{T}_{3}$ bound to nuclear sites in the bovine liver and mammary gland with high affinity and specificity. Affinity and capacity of the mammary and hepatic nuclear binding sites were analogous to those of TR in other species. The binding capacity of mammary nuclei was approximately $60 \%$ of the binding capacity of liver nuclei, supporting the concept that mammary epithelial cells are sensitive to thyroid hormones. Administration of bST or bGRF did not alter hepatic or mammary TR number or affinity, nor was the expression of TR or RXR isoforms in mammary tissue altered. Data do not support the hypothesis that administration of bST or bGRF alters sensitivity of mammary tissue to thyroid hormones by altering expression of thyroid hormone receptors.

\section{ACKNOWLEDGMENTS}

The authors are grateful for the excellent technical assistance of Richard A. Aschenbrenner and David L. Wood. Words cannot express our gratitude to our mentor and friend H. Allen Tucker, who died July 15, 2009.

\section{REFERENCES}

Aceves, C., and C. Valverde. 1989. Type I, 5'-monodeiodinase activity in the lactating mammary gland. Endocrinology 124:2818-2820.

Bernal, J., and L. J. DeGroot. 1977. Thyroid hormone receptors: Release of receptor to the medium during in vitro incubation of isolated rat liver nuclei. Endocrinology 100:648-655.

Binelli, M., W. K. Vanderkooi, L. T. Chapin, M. J. Vandehaar, J. D. Turner, W. M. Moseley, and H. A. Tucker. 1995. Comparison of growth hormone-releasing factor and somatotropin: Body growth and lactation of primiparous cows. J. Dairy Sci. 78:2129-2139. 
Blum, J. W., P. Kunz, H. Leuenberger, K. Gautschi, and M. Keller. 1983. Thyroid hormones, blood plasma metabolites and hematological parameters in relationship to milk yield in dairy cows. Anim. Prod. 36:93-104.

Capuco, A. V., E. E. Connor, and D. L. Wood. 2008. Regulation of mammary gland sensitivity to thyroid hormones during the transition from pregnancy to lactation. Exp. Biol. Med. (Maywood) 233:1309-1314.

Capuco, A. V., S. Kahl, L. J. Jack, J. O. Bishop, and H. Wallace. 1999. Prolactin and growth hormone stimulation of lactation in mice requires thyroid hormones. Proc. Soc. Exp. Biol. Med. 221:345-351.

Capuco, A. V., J. E. Keys, and J. J. Smith. 1989. Somatotrophin increases thyroxine- 5 '-monodeidonase activity in lactating mammary tissue of the cow. J. Endocrinol. 121:205-211.

Dahl, G. E., L. T. Chapin, W. M. Moseley, and H. A. Tucker. 1993. Galactopoietic effects of recombinant somatotropin and growth hormone-releasing factor in dairy cows. J. Dairy Sci. 76:15501557.

DeGroot, L. J., A. Nakai, A. Sakurai, and E. Macchia. 1989. The molecular basis of thyroid hormone action. J. Endocrinol. Invest. 12:843-861.

Falcone, M., T. Miyamoto, F. Fierro-Renoy, E. Macchia, and L. J. DeGroot. 1992. Antipeptide polyclonal antibodies specifically recognize each human thyroid hormone receptor isoform. Endocrinology 131:2419-2429.

Fukuda, H., K. Ohshima, M. Mori, I. Kobayashi, and M. A. Greer. 1980. Sequential changes in the pituitary-thyroid axis during pregnancy and lactation in the rat. Endocrinology 107:1711-1716.

Graham, W. R. 1934. The action of thyroxine on the milk and milk-fat production of cows. Biochem. J. 28:1368-1371.

Harvey, C. B., and G. R. Williams. 2002. Mechanism of thyroid hormone action. Thyroid 12:441-446.

Jack, L. J. W., S. Kahl, D. L. St Germain, and A. V. Capuco. 1994. Tissue distribution and regulation of 5 '-deiodinase processes in lactating rats. J. Endocrinol. 142:205-215.

Jimenez-Krassel, F., M. Binelli, H. A. Tucker, and J. J. Ireland. 1999. Effect of long-term infusion with recombinant growth hormonereleasing factor and recombinant bovine somatotropin on development and function of dominant follicles and corpora lutea in Holstein cows. J. Dairy Sci. 82:1917-1926.

Kahl, S., A. V. Capuco, M. Binelli, W. K. Vanderkooi, H. A. Tucker, and W. M. Moseley. 1995. Comparison of growth hormone-releasing factor and somatotropin: Thyroid status of lactating, primiparous cows. J. Dairy Sci. 78:2150-2158.

Kahl, S., A. V. Capuco, and J. Bitman. 1987. Serum concentrations of thyroid hormones and extrathyroidal thyroxine- 5 '-monodeiodinase activity during lactation in the rat. Proc. Soc. Exp. Biol. Med. 184:144-150.

Keijzer, R., P.-J. E. Blommaart, W. T. Labruyère, J. L. M. Vermeulen, B. Z. Doulabi, O. Bakker, D. Tibboel, and W. H. Lamers. 2007. Expression of thyroid hormone receptors A and B in developing rat tissues; Evidence for extensive posttranscriptional regulation. J. Mol. Endocrinol. 38:523-535.

Labarca, C., and K. Paigen. 1980. A simple, rapid and sensitive DNA assay procedure. Anal. Biochem. 102:344-352.
Liesman, J. S., J. P. McNamara, A. V. Capuco, M. Binelli, W. K. Vanderkooi, R. S. Emery, H. A. Tucker, and W. M. Moseley. 1995. Comparison of growth hormone-releasing factor and somatotropin: Lipid and glucose metabolism in dairy cows. J. Dairy Sci. 78:2159-2166.

NRC. 1989. Nutrient Requirements of Dairy Cattle. 6th rev. ed. Natl. Acad. Sci., Washington, DC.

Oetting, A., and P. M. Yen. 2007. New insights into thyroid hormone action. Best Pract. Res. Clin. Endocrinol. Metab. 21:193-208.

Oppenheimer, J. H. 1979. Thyroid hormone action at the cellular level. Science 203:971-979.

Oppenheimer, J. H., and H. L. Schwartz. 1986. Thyroid hormone action at the nuclear level. Pages 383-415 in Thyroid Hormone Metabolism. G. Hennemann, ed. Marcel Dekker, Inc., New York, NY.

Oppenheimer, J. H., H. L. Schwartz, C. N. Mariash, W. B. Kinlaw, N. C. W. Wong, and H. C. Freake. 1987. Advances in our understanding of thyroid hormone action at the cellular level. Endocr. Rev. 8:288-308.

Pezzi, C., P. A. Accorsi, D. Vigo, N. Govoni, and R. Gaiani. 2003. 5 '-deiodinase activity and circulating thyronines in lactating cows. J. Dairy Sci. 86:152-158.

Refsal, K., R. F. Nachreiner, and C. R. Anderson. 1984. Relationship of season, herd, lactation, age, and pregnancy with serum thyroxine and triiodothyronine in Holstein cow. Domest. Anim. Endocrinol. 1:225-234.

Sap, J., A. Muñoz, K. Damm, Y. Goldberg, J. Ghysdael, A. Leutz, H. Beug, and B. Vennström. 1986. The c-erb-A protein is a highaffinity receptor for thyroid hormone. Nature 324:635-640.

Scatchard, G. 1949. The attractions of proteins for all small molecules and ions. Ann. N. Y. Acad. Sci. 51:660-672.

Silva, J. E., and P. R. Larsen. 1986. Regulation of thyroid hormone expression at the prereceptor and receptor levels. Pages 441-500 in Thyroid Hormone Metabolism, G. Hennemann, ed. Marcel Dekker Inc., New York, NY.

Tucker, H. A. 1981. Physiological control of mammary growth, lactogenesis, and lactation. J. Dairy Sci. 64:1403-1421.

Valverde-R, C., and C. Aceves. 1989. Circulating thyronines and peripheral monodeiodination in lactating rats. Endocrinology 124:1340-1344.

Vanderkooi, W. K., M. J. Vandehaar, B. K. Sharma, M. Binelli, H. A. Tucker, R. M. Akers, and W. M. Moseley. 1995. Comparison of growth hormone-releasing factor and somatotropin: The somatotropic axis in lactating primiparous cows. J. Dairy Sci. 78:21402149.

Weinberger, C., C. C. Thompson, E. S. Ong, R. Lebo, D. J. Gruol, and R. M. Evans. 1986. The c-erb-A gene encodes a thyroid hormone receptor. Nature 324:641-646.

Wilson, D. B., and R. C. Gorewit. 1980. Specific thyroxine receptors in mammary cytosol from lactating cattle. Biochem. Biophys. Res. Commun. 95:807-815.

Yen, P. M. 2001. Physiological and molecular basis of thyroid hormone action. Physiol. Rev. 81:1097-1142. 